\title{
CONTROLLED TRIAL OF METHACYCLINE AND TETRACYCLINE IN THE TREATMENT OF NON-SPECIFIC URETHRITIS*
}

\author{
BY \\ D. J. M. WRIGHT $\uparrow$ \\ St. Bartholomew's Hospital, London, E.C.1.
}

Methacycline is more quickly absorbed and possibly more slowly cleared than tetracycline; it has a longer duration of action and it produces higher serum levels and higher antibacterial levels in vitro (Kunin, 1962; Remington and Finland, 1962; Te-Wen Chang and Weinstein, 1962; Limson and Guevara, 1963). To determine whether it might be more effective than tetracycline in the treatment of non-specific urethritis, the two drugs were compared in a double-blind clinical trial.

\section{Material and Methods}

Patients with obvious discharge were chosen so as to allow more clear-cut evidence of cure or failure. The following were excluded: patients with a history of hepatic, renal, or bowel disease; those in whom urethritis had been treated in the last 6 months or who had taken antibiotics for some other reason; and those with limited ability to understand English. A total of 66 men with non-specific urethritis, in one case complicated by Reiter's disease, entered the trial. Gonorrhoea and Trichomonas vaginalis urethritis were excluded on the results of Gram-stained smears and culture of the urethral discharge and on findings in wet smears.

Alternate cases were treated with methacycline, the others with tetracycline; the drugs were supplied in identical form, each patient being instructed to take two capsules every 8 hours for 5 days. Each dose of methacycline was of $300 \mathrm{mg}$; that of tetracycline was $500 \mathrm{mg}$.

$\star$ Received for publication July $20,1967$.

†Present address: Guy's Hospital, London, S.E.1.
Patients were asked not to take capsules within 2 hours of a meal (Kirby, Roberts, and Bardick, 1961) and to refrain from sexual activity and drinking alcohol while under surveillance. Follow-up attendances varied with the progress in each case. When persistence or recurrence of urethritis was recognized; cases were re-treated with the same double-blind procedure. At the conclusion of the trial the type of drug given to each patient at the initial or secondary treatment was revealed to the physician and the results were assessed on the basis of the recorded findings at 1 week, and 1, 2, and 3 months after starting treatment. The criteria for "cure" were the cessation of symptoms and the absence of urethral discharge coupled with a clear voided urine held for 5 hours (Harkness, 1950). No attention was paid to clear urethral secretion, early morning smears containing only occasional leucocytes, or to urine containing mucus. Cases of presumed relapse were not distinguished from those of presumed re-infection-both were classed as failure of treatment.

\section{Results}

Three of those taking methacycline suffered nausea and one other mild diarrhoea; in all the remaining cases there were no reports of side-effects.

All 66 cases could be assessed at the first week, but by the completion of the trial 31 per cent. of the patients had defaulted.

The results at each period of assessment are shown in Table I. The cumulative failure rates and

TABLE I

RESULTS AFTER DIFFERENT LENGTHS OF TIME

\begin{tabular}{|c|c|c|c|c|c|c|c|c|}
\hline \multirow{3}{*}{ Drug } & \multicolumn{8}{|c|}{ Time after Starting Treatment } \\
\hline & \multicolumn{2}{|c|}{$1 \mathrm{wk}$} & \multicolumn{2}{|c|}{$1 \mathrm{mth}$} & \multicolumn{2}{|c|}{$2 \mathrm{mths}$} & \multicolumn{2}{|c|}{3 mths } \\
\hline & Cure & Failure & Cure & Failure & Cure & Failure & Cure & Failure \\
\hline Methacycline & 29 & 4 & 14 & 9 & 9 & 3 & 7 & 0 \\
\hline Tetracycline & 31 & 2 & 14 & 9 & 8 & 0 & 5 & 1 \\
\hline
\end{tabular}


the estimated maximum cure rates are shown in Table II. The differences implying the superiority of tetracycline are not statistically significant.

Of the 28 cases of failure of initial treatment, 25 were given re-treatment (secondary treatment); the results are shown in Table III. As with initial treatment the results with the two drugs were not significantly different.

All patients had a subjective cure within 3 or 4 days. Subsequently one had a subjective relapse, and complained of urethral discharge. Eight had a minimal subjective relapse, in addition to objective signs, and nineteen had a relapse based on only a single physical sign -an early morning smear with many leucocytes.

The occurrence of previously treated non-specific urethritis did not affect the response to treatment in this trial. However, patients with symptoms of between 4 and 7 days' duration did better than those with a shorter duration of symptoms. It was found, perhaps not surprisingly, that those with a history of previously treated urethritis tended to attend for treatment sooner and admitted more recent sexual exposure.

\section{Discussion}

The negligible difference in response to the two drugs is hardly surprising when it is taken into account that more methacycline than tetracycline is rendered inert by being protein-bound, despite producing a higher serum level.

Thus Kunin (1962) showed experimentally that 35.6 per cent. of tetracycline and 78.5 per cent. of methacycline became protein-bound. Te-Wen Chang and Weinstein (1962) showed that there was decreased anti-bacterial activity of antibiotic if incubated in vitro with serum, and English (1966) showed that the percentage inactivation corresponded with the theoretical prediction of proteinbinding. The percentage inactivation of methacycline was 81 per cent. and that of tetracycline 59 per cent. Thus the apparent increased methacycline levels may be less active than anticipated and the prolonged presence of the drug in body fluids merely reflects its protein-binding propensity coupled with a slow release. In this respect it is interesting to note that, if tetracycline is given to patients with hypoproteinaemia, the normal dose may have a toxic action upon them, for example, a catabolic effect and liver toxicity. The state of nutrition of the patients in the present series was excellent and the toxic effects were negligible.

Comparisons should not be drawn between the results recorded in the present trial and those in a recent trial of methacycline in non-specific urethritis (Morton and Wray, 1966), as the latter trial was uncontrolled and a different dosage was employed.

The tetracycline dosage used in the present trial seems to have had a suppressive rather than a curative action, in that the major signs of the disease were quickly reversed but the minimal signs continued. In nineteen out of 28 of the cases of failure there was persistence of many leucocytes in early morning urethral smears.

This action may relate to the fact that TRIC agent is the cause of some cases of non-specific urethritis. Jawetz (1964), quoting Watkins, observed that "... tetracycline is not viricidal and has no effect on TRIC agent in vitro in the absence of host cells, but it inhibits the growth and formation of their lethal products".

TABLE II

CURE RATES AFTER 1 AND 3 MONTHS

\begin{tabular}{|c|c|c|c|c|c|c|}
\hline \multirow[t]{2}{*}{ Drug } & \multirow[t]{2}{*}{ No. of Cases } & \multirow{2}{*}{$\begin{array}{l}\text { No. of } \\
\text { Known } \\
\text { Failures }\end{array}$} & \multirow{2}{*}{$\begin{array}{l}\text { Percentage } \\
\text { Cumulative } \\
\text { Failure Rate }\end{array}$} & \multirow{2}{*}{$\begin{array}{c}\text { Best } \\
\text { Estimated } \\
\text { Cure Rate } \\
\text { (per cent.) }\end{array}$} & \multicolumn{2}{|c|}{$\begin{array}{l}\text { Maximum Estimated Cure } \\
\text { Rate (per cent.) after }\end{array}$} \\
\hline & & & & & $1 \mathrm{mth}$ & $3 \mathrm{mths}$ \\
\hline Methacycline & 33 & 16 & 50 & 50 & 54 & 30 \\
\hline Tetracycline & 33 & 12 & 33 & 67 & 56 & 33 \\
\hline
\end{tabular}

TABLE III

RESULTS OF RE-TREATMENT AFTER DIFFERENT LENGTHS OF TIME STARTING RE-TREATMENT

\begin{tabular}{|c|c|c|c|c|c|c|c|c|}
\hline \multirow{3}{*}{ Drug } & \multicolumn{8}{|c|}{ Time after Starting Re-treatment } \\
\hline & \multicolumn{2}{|c|}{$1 \mathrm{wk}$} & \multicolumn{2}{|c|}{$1 \mathrm{mth}$} & \multicolumn{2}{|c|}{2 mths } & \multicolumn{2}{|c|}{$3 \mathrm{mths}$} \\
\hline & Cure & Failure & Cure & Failure & Cure & Failure & Cure & Failure \\
\hline Methacycline & 11 & 2 & 8 & 1 & 6 & 1 & 5 & 0 \\
\hline Tetracycline & 9 & 3 & 6 & 2 & 4 & 1 & 1 & 0 \\
\hline
\end{tabular}




\section{Summary}

66 patients with non-specific urethritis took part in a double-blind trial of methacycline and tetracycline, the drugs being given in equivalent dosage for a course of 5 days. The cumulative failure rates were almost identical. The best estimated cure rate was 67 per cent. for tetracycline and 50 per cent. for methacycline, but this difference was not statistically significant. The reason advanced for the lack of superiority of methacycline over tetracycline is that effects of increased serum levels of methacycline are probably counteracted by protein-binding. The mode of action of the tetracycline group is probably suppressive rather than curative. It is thought that, in future trials, serum levels should be estimated, so as to allow for variable degrees of absorption.

I should like to acknowledge the help given by Dr. C. S. Nicol, of St. Bartholomew's Hospital, for permitting me to use his patients in this study, and to thank Mr. N. P. Allen, of Pfizer Ltd., for the gift of methacycline used in the trial.

\section{REFERENCES}

ENglish, A. R. (1966). Proc. Soc. exp. Biol. N.Y., $122,1104$.

HARKNESS, A. H. (1950). "Non-gonococcal Urethritis", p. 27. Livingstone, Edinburgh.

JAWETZ, E. (1964). Ann. rev. Microbiol., 18, 317.

KIRBY, W., ROBERTS, C. E., and BURDICK, R. E. (1961). In "Antimicrobial Agents and Chemotherapy1960", p. 286. American Society of Microbiology, Detroit, Michigan, U.S.A.
Kunin, C. M. (1962). Proc. Soc. exp. Biol. N.Y., 110, 311.

Limson, B. M., and Guevara, R. (1963). Curr. ther. Res., 5, 249.

Morton, R. S., and WRAY, P. M. (1966). Brit. F. vener. Dis., 42, 195.

Remington, J. S., and FinLand, M. (1962). Clin. Pharmacol. Ther., 3, 284.

Te-Wen Chang and Weinstein, L. (1962). Antibiot. and Chemother., 12, 676.

Une expérience contrôlée de l'emploi de la méthacycline et de la tétracycline dans le traitement de l'urétrite non-spécifique

\section{RÉsumé}

66 malades atteints d'urétrite non-spécifique ont pris part à une expérience de traitement à double insu par la méthacycline et la tétracycline, ces médicaments étant donnés en doses équivalentes pour un traitement de 5 jours. Les taux cumulatifs d'insuccès étaient presqu'identiques. Les meilleurs taux estimés de cure étaient de 67 pour cent pour la tétracycline et de 50 pour cent pour la méthacycline, mais cette différence n'est pas statistiquement significative. La raison offerte pour expliquer pourquoi la méthacycline n'est pas supérieure à la tétracycline est que les effets des taux accrus de la méthacycline dans le sérum sont probablement neutralisés par la liaison avec les protéines. Le mode d'action de la tétracycline est probablement d'atténuer la maladie plutôt que de la guérir. On pense que dans les expériences à venir, le taux sérique devrait être estimé afin de prendre en considération les différents dégrés d'absorption. 